\title{
A Literature Study of Science Process Skill toward Deaf and Hard of Hearing Students
}

\author{
$1^{\text {st Ediyanto }}$ \\ Graduate School for International \\ Development and Cooperation \\ Hiroshima University \\ Kagamiyama, Higashi-Hiroshima City, \\ Japan \\ corresnponding author: \\ d171740@hiroshima-u.ac.jp \\ $4^{\text {th }}$ Norimune Kawai \\ Department of Special Needs Education, \\ Graduate School of Education, \\ Hiroshima University, Hiroshima, Japan \\ nkawai@hiroshima-u.ac.jp
}

\author{
$2^{\text {nd }}$ Iva N. Atika \\ Graduate School for International \\ Development and Cooperation \\ Hiroshima University \\ Kagamiyama, Higashi-Hiroshima City, \\ Japan \\ m171387@hiroshima-u.ac.jp
}

\author{
$3^{\text {rd }}$ Masashi Hayashida \\ Department of Special Needs Education, \\ Graduate School of Education, \\ Hiroshima University, Hiroshima, Japan \\ mhyshd@hiroshima-u.ac.jp
}

\begin{abstract}
The purpose of science education is that students can individually master the science process skill and engage in inquiry. The basic science process skills consist of observing, communicating, classifying, measuring, inferring and predicting. Meanwhile, integrated science process skills are controlling variables, defining operationally, formulating hypotheses, interpreting data, experimenting and formulating models. Science for All indicates that science should be accessible by all learners including deaf and hard of hearing students. Low learning achievement of deaf and hard of hearing students do not come from a low intellectual ability, but due to the intelligence that did not get a chance to develop optimally. Purpose of this study is to explain that deaf and hard of hearing students can master the science process skills. A total of 6 journals on the topic of science process skills and deaf and hard of hearing students were reviewed. These pieces of literature were collected via Hiroshima University Library, and then analyzed and interpreted in accordance with the objectives of the study. Based on this literature review, deaf and hard of hearing students can understand about basic science process skills and develop more positive attitudes towards science. If teachers can apply the right learning model and are supported with good facilities, it is possible that deaf and hard of hearing students will be able to learn about the integrated science process skills.
\end{abstract}

Keyword-Science process skills, Deaf and Hard of Hearing Students

\section{INTRODUCTION}

Science is one of the most important subjects that are taught in the schools [1] [Appendix 1]. The purpose of science education is that students individually master the science process skill [2], [3], [4] and to teach students how to get involved in the inquiry [5]. In other words, a student should have integrated skills, knowledge, and attitudes to develop a better understanding of the scientific concept. Understanding of science process skills refers to skills that must be owned by the scientist on the process of scientific discovery. These skills divided into two groups: basic and integration. Basic science process skills consist of observing, communicating, classifying, measuring, inferring and predicting. Meanwhile, integrated science process skills are controlling variables, defining operationally, formulating hypotheses, interpreting data, experimenting and formulating models [6], [7], [8], [9], [10]. Science process skills are a necessary tool to produce and use scientific information, to perform scientific research, and solve problems [4].

Some research studies on the implementation of science process skills have been conducted. Implementation of science process skills can be conducted with several models of learning such as project-based learning and interactive computer simulations. By Project-based learning, science process skills are a common practice for the student to develop skills in cognitive, psychomotor and affective [11], [12], [13]. In other studies, by using interactive computer simulations, students can significantly improve science process skill and mastery of the concept of direct current electrical circuits [14]. The scientific argumentation had a significant effect on integrated science process skills expect for the designing experiments skills [15]. While for research attitudes toward science process skills, students have a significant correlation between knowledge level of science process skills and attitudes toward science [5]. In some studies, it was observed that students that mastery science 
process skills can provide a good effect on students' attitudes in learning [11], [16], [17].

Science for All indicated that science should be accessible by all learners [18] including deaf and hard hearing (DHH) student. Science education should help students in developing an understanding and habits of thinking, which is needed to solve problems in life [19]. Haenudin [20] mentioned the low learning achievement of children with hearing impairment does not come from their low cognitive abilities. Deaf and hard of hearing students have good academic status and progress in general education classrooms [21]. Deaf and hard of hearing students also have an increased scientific concept with appropriate learning models.

In this paper explain that deaf and hard of hearing students have the ability to improve their achievement in science learning. In the right way, deaf and hard of hearing students can have good skill process skills. Therefore, the purpose of the current study is to explain that deaf and hard of hearing (DHH) students can master science process skills. Then the general research question in this literature review is how deaf and hard of hearing (DHH) students can mastery science process skills?

\section{METHOD}

This study was conducted by reviewing articles published in the journal. The selected research articles are a study published from 2009 to 2017. The review of the selected literature was conducted through an article search on the Hiroshima University Library database (website: http://www.lib.hiroshima-u.ac.jp/?lang=english). Six relevant peer-reviewed have been chosen in the current study and focused in the implementation of science learning, science process skills and Deaf and Hard of Hearing students in the school.

\section{A. Selection of the Articles}

Articles started by using the website http://www.lib.hiroshima-u.ac.jp/?lang=english for peerreviewed or journal articles from 2009 to 2017. With titles that contained words of "science process skills." In the beginning, a total of 9,196 articles were available on the Hiroshima University Library database fell within these criteria. To restricting this search, only articles are available in a full-text form and according to the selected keywords. Then in the limit again with the article publishing year starting in 2009 until 2017. Therefore, based on this search, articles that match with keywords and search restrictions found as many as 416 articles.

At the second phase, we select journals that focus on science learning or science process skills toward deaf and hard hearing students. We excluded from the corpus articles that were not mentioned of science (biology, physics, and chemistry), Deaf and Hard of Hearing student, or 'general education keywords), such as 'learning,' 'instruction,' or 'teaching.' At this stage selection process of relevant articles, there no article related science process skills toward Deaf and Hard of Hearing students. We found one article related science concepts toward Deaf and Hard of Hearing students and one article science in inquiry toward Deaf and Hard of Hearing students. Therefore, the author focused in accordance to Deaf and Hard of Hearing student in science learning. Six articles were identified for thorough analysis according to research questions.

\section{B. Analysis}

The literature reviews were conducted utilizing a bestevidence approach, based on an analysis of the six journal articles selected according to the research question. Each article was analyzed by two people and one-verification. In this process, the authors used the same criteria that were mentioned above, according to questions.

\section{Categorizations}

Each article was reviewed in light of the developing set of research questionsuntil the entire set of data was treated. We also ensured that each article had the potential to fit into more than one finding (and sometimes many more). For example, some articles show different types of achievements. Therefore, we divided the results of the six science learning toward Deaf and Hard of Hearing students' domains (i.e., applications and connections domain, attitude domain, creativity domain, process domain, and concept domain).

\section{RESULTS}

\section{A. The General Information of Science Process Skill}

Definition of science process skills concept is not explained in the article reviewed in this studies. The explanation of the science process skills concept is referenced from other research sources and a book on the concept of science process skill. The definition of science process skill in this studies comes from the Journal Publication by Padilla [6] entitled "The Science Process Skills", from the book by Rezba et.al. [22] entitled "Learning and Assessing Science Process Skills" and book by Harlen\& Elstgeest [23] entitled "UNESCO Sourcebook for Science in Primary School". According to Padilla [6], the scientific method, scientific thinking, and critical thinking have been terms used at various times to describe these science skills. Science process skills are Science - A Process Approach (SAPA), these skills are defined as a set of broadly transferable abilities, appropriate to many of the science disciplines and reflective of the behavior of scientists. According to Harlen \& Elstgeest [23], science process skill is the interaction of children with their environment in a scientific manner happens through process skills such as handling, manipulating, observing, questioning, and interpreting. Process skills are thus the route by which 
children explore and gain evidence which they use in developing ideas.
Science process skills divided into two groups: basic and integration. The division of science process skills can be explained in Figure 1.

\begin{tabular}{|c|c|c|c|c|}
\hline \multicolumn{5}{|c|}{ Experimenting } \\
\hline \multicolumn{2}{|c|}{ Designing Investigations } & \multicolumn{2}{|c|}{ Analyzing Investigations } & Describing Relationships \\
\hline \multirow{3}{*}{$\begin{array}{c}\text { Constructing } \\
\text { Hypotheses }\end{array}$} & \multirow{3}{*}{\multicolumn{2}{|c|}{$\begin{array}{l}\text { Acquiring and } \\
\text { Processing Data }\end{array}$}} & Defining Variables & Constructing Graphs \\
\hline & & & Operationally & \multirow{2}{*}{$\begin{array}{c}\text { Constructing a Table of } \\
\text { Data }\end{array}$} \\
\hline & & & Identifying Variables & \\
\hline \multicolumn{2}{|c|}{ Predicting } & & Measuring & \multirow{2}{*}{ Communication } \\
\hline \multicolumn{2}{|c|}{ Inferring } & & Classifying & \\
\hline \multicolumn{5}{|c|}{ Observing } \\
\hline
\end{tabular}

Figure 1: Process skills as a foundation to increase the understanding of science(source: Rezba et al. [21])

\section{The Basic Science Process Skills}

According to Padilla [6], basic science process skills are observing, inferring, measuring, communicating, classifying and predicting. Observing is using the senses to gather information about an object or event. Example: Describing a pencil as yellow. Inferring is making an "educated guess" about an object or event based on previously gathered data or information. Example: Saying that the person who used a pencil made many mistakes because the eraser was well worn. Measuring is using both standard and non-standard measures and estimates to describe the dimensions of an object or event. Example: Using a meter stick to measure the length of a table in centimeters. Communicating is using words or graphic symbols to describe an action, object or event. Example: Describing the change in the height of a plant over time in writing or through a graph. Classifying is grouping or ordering objects or events into categories based on properties or criteria. Example: Placing all rocks having certain grain size or hardness into one group. Predicting is stating the outcome of a future event based on a pattern of evidence. Example: Predicting the height of a plant in two weeks' time based on a graph of its growth during the previous four weeks.

According to Rezba et. al. [22], basic science process skills are the skills we use when we $d o$ science. Children use these skills to explore the natural world actively. They use their senses to observe object and events, and they look for patterns in those observations. They also frequently predictthe possibility of the outcomes before they executed it. They then infer explanations and change their inferences as new information becomes available. They classify to from new concepts by searching for similarities and differences.
Orally and in writing, they communicate what they know and are able to do. To quantify descriptions of objects and events, they measure. These skills are essential to improve the science lessons in the elementary classroom.

\section{The Integrated Science Process Skills}

According to Padilla [6], integrated science process skills are controlling variables, defining operationally, formulating hypotheses, interpreting data, experimenting and formulating models. Controlling variables is being able to identify variables that can affect an experimental outcome, keeping most constant while manipulating only the independent variable. Example: Realizing through past experiences that amount of light and water need to be controlled when testing to see how the addition of organic matter affects the growth of beans. In practice, defining it means stating how to measure a variable in an experiment. Example: Stating that bean growth will be measured in centimeters per week. Formulating hypotheses is stating the expected outcome of an experiment. Example: The more significant the amount of organic matter added to the soil, the higher the bean growth. Interpreting data is organizing data and drawing conclusions from it. Example: Recording data from the experiment on bean growth in a data table and forming a conclusion which relates trends in the data to variables. Experimenting - being able to experiment, including asking an appropriate question, stating a hypothesis, identifying and controlling variables, operationally defining those variables, designing a "fair" experiment, conducting the experiment, and interpreting the results of the experiment. Example: The entire process of experimenting with the effect of organic matter on the growth of bean plants. Formulating models is creating a mental or physical model of a process or an event. Examples: The 
model of how the processes of evaporation and condensation interrelate in the water cycle.

According to Rezba et al. [22], when you mastered the basic science process skills, you will ready to learn the skills that lead to experimenting, the integrated process skills. By combining the integrated process skills with the basic science process skills, it can create a classroom climate where children explore, investigate, and discover. In the classroom where children are learning the integrated process skills, they inquire about how things work, and they seek answers to their questions by designing and conducting experiments. Rather than relying on their teacher and textbook to supply all the answers, these children ask themselves, how can we found it?

The integrated science process skills include identifying variables, constructing hypotheses, analyzing investigations, tabulating and graphing data, defining variables, designing investigations, and experimenting. Learning these skills empowers students to answer many of their questions. Students who have learned the integrated skills have the tools to interpret what they observe, to make inferences and predictions about their observations, and to design investigations to test their ideas.

The integrated process skills depend upon the basic process skills; the basic process skills provide the foundations for more complex integrated skills. For example, predicting skills are used to construct hypotheses. A hypothesis is a particular kind of prediction that sets the stage for designing a scientific investigation. You will find, as your students also will, that experimenting leads to asking more questions and conducting more experiments. Experimenting is a form of problem-solving that requires the integration of the other skills. Each time you learn a new skill, ask yourself the following questions and use your answers to guide your instructional decisions when teaching science.

\section{B. Science Learning toward Deaf and Hard of Hearing Students}

Knowledge and understanding of deaf and hard of hearing students on the concept of science is measured by tests [Appendix 1], [Appendix 2], [Appendix 3]. Hearing students are more competent on scientific experience, reasoning and abstraction than deaf students [Appendix 1]. The concepts of the science of hearing and deaf students are not different from their school. Currently, the possible reason is the deaf students are not being involved in scientific education and experiments as they are not given an opportunity to use laboratories in schools. In another article, deaf and hard of hearing students can learn in both Direct Communication and Interpreted Education setting [Appendix 2]. Students learn much better in the Direct Communication than Interpreted Education condition [Appendix 2]. In the study of deaf students' understanding of fractional concepts [Appendix 3], results indicated an in-depth understanding of fractional magnitude/size when comparing two fractions. However, putting some fractions in order from the smallest to the largest was a struggle for the participants. The findings also support the call for increased incidental learning opportunities between deaf and hard of hearing children and students.

Other results about articles in science learning toward deaf and hard of hearing students are learning methods [Appendix 2], [Appendix 4], [Appendix 5], [Appendix 6].A variety of learning methods that can be applied to science learning toward deaf and hard of hearing students. One journal discusses direct instruction versus interpreted instruction [Appendix 2]; others mention experimental methodology [Appendix 4], AR-book by blended learning strategies [Appendix 5], and inquiry-based biology laboratory classes [Appendix 6]. On the use of two situations (direct instruction versus interpreted instruction) on science learning, analyses revealed that all students performed better on the post-test compared to their pre-test performance. As a group, the children learned from the lectures. There were no significant differences between the students' pre-test performance. However, analyses of their post-test performance revealed that the students learned much better in the Direct Communication than in the Interpreted Education condition (see Figure 2) [Appendix 2]. In a study using experimental methods in science learning in deaf students [Appendix 4], the result suggested a very positive impact. The experimental methodology led to an increased interest in science by the deaf students and most of the students who took part in activities presented language refinement, increased self-esteem, and self-confidence. The finding of the previous study [Appendix 5] conveys that the deaf students are capable in visualizing picture, they like pictures compared to $2 \mathrm{D}$ or sketch pictures, they have good ability in visual communication such as sign language compared to finger spelling and written text. If they are able to spell the word by using finger spelling, they are also able to write it on, and they are able to give good reason according to the picture given. In a study using inquiry-based biology laboratory classes [Appendix 6], before laboratory classes, deaf students reported communication difficulties in the classroom. After laboratory classes, students' repeated engagement with doing science themselves supported positive growth of scientific attitudes, student appreciated and enjoyed the hands-on, student-driven experimentation in the inquiry-based laboratory classes, students reported that peer collaboration was a major feature of inquiry learning and students' described the inquiry-based learning environment as a "positive environment," which is essential to support attitudinal growth.Analysis of reflection assignments and interviews shows that students deaf, hard of hearing and hearing signing students developed positive attitudes toward science and scientific attitudes after 
participating in inquiry-based biology laboratory classes [Appendix 6].

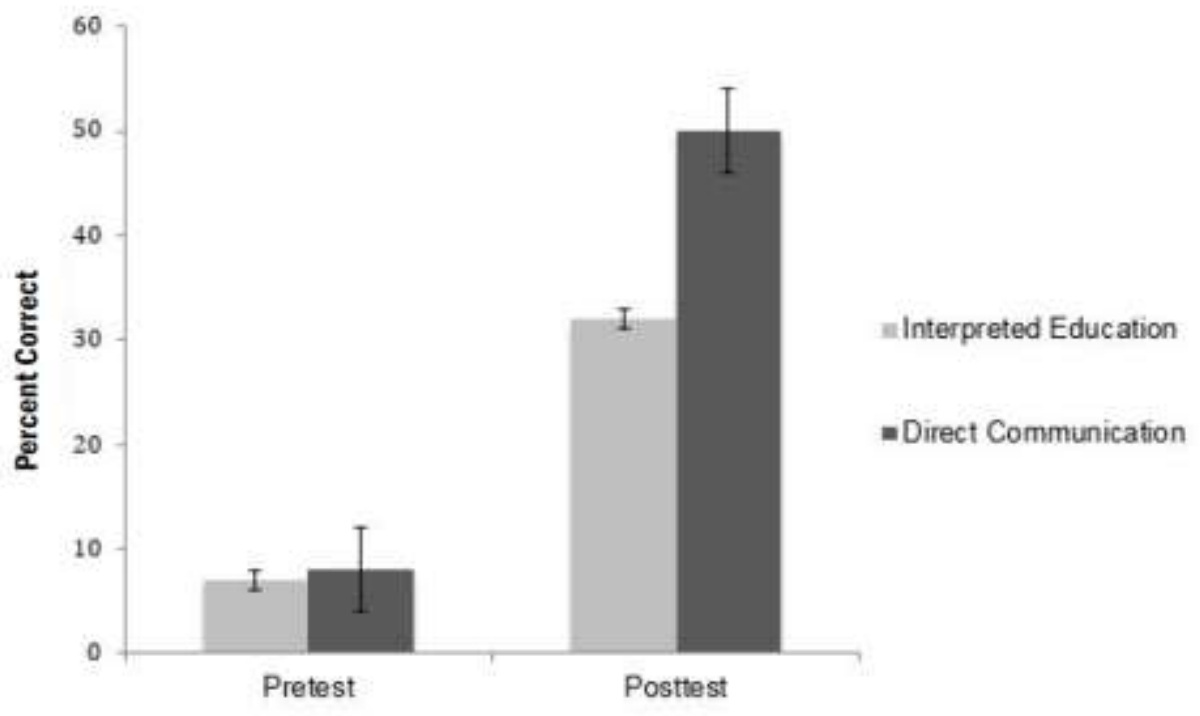

Figure2:Participants' performance on the science Pre-test and post-test in the two learning situation. Error bars represent the standard error of the mean.

\section{DISCUSSIONS}

Science Process Skills toward Deaf and Hard of Hearing Students

Science education should enable the learner to: know the fact and principles of science and its application, consistent with the stage of cognitive development, acquire the skills and understand the methods and processes that lead to generation and validation of scientific knowledge [23]. In science learning activities, it is so essential to developing science process skills to ensure that students master the concepts taught well [24], [14]. Students who have the good quality in science process skills, then student be able to make the process of scientific quality, and process quality science will produce a quality product. Science process skill is known as procedural skill, experimental and investigating science habits of mind or scientific inquiry abilities [2]

A variety of learning methods can be used so that students have good science process skills. Learning method can be used using interactive computer simulation [14] and project-based learning [11], [12], [13]. Science inquiry learning model using an interactive computer simulation can significantly improve science process skills and mastery of the concept of direct current circuits [14]. Science process skills that improve are observation, inference, prediction, communication, hypothesis, experiment design and implementation of the concept. If science inquiry learning model using an interactive computer simulation applied to science learning toward hard and hard of hearing students, they are likely to master the science process skills. Deaf students were capable of good at visualizing text [5].

Students in science learning with project-based learning have a better mastery of science process skills than students who do not learn with project-based learning [11]; [12]. By project-based learning, the teacher can apply science process skill of exploring, comparing, observing, communicate, classifying, measuring and using members, draw inferences and make hypotheses [13]. If projectbased learning is applied in science learning on the deaf and hard of hearing students, then it is likely that their skill skills will also increase.

\section{CONCLUSION}

The literature review indicates that deaf and hard of hearing students can master the science processskills. Science processskills toward deaf and hard of hearing students can be mastered if taught with the right learning model. Teachers can use the learning model as follows inquiry-based biology laboratory classes and AR-book by blended learning. Deaf and difficulties of hearing students can learn in both direct and more accessible communication, interpreted instruction with preferred visual. So interactive computer simulation can be used and proved by further research. While for project-based learning, it is necessary to do further research. 


\section{FUTURE DIRECTIONS}

The findings in this literature review have indicated that deaf and hard of hearing students can master the science processskills. This study strongly shows that research on implementation of science process skills approach in deaf and hard of hearing students are highly recommended to be conducted to identify its impacts on students' achievement through science learning. Learning model that can be used is inquiry-based biology laboratory classes, AR-book blended learning, and project-based learning in combination with Interactive computer simulation.

\section{ACKNOWLEDGEMENT}

The authors highly appreciate to Dr. Tuswadi (researcher in Waku Pro Research Centre Hijiyama University) who has kindly checked the English of this research publication.

\section{REFERENCES}

[1] B. Akram, R. Mehboob, A. Ajaz, \& R. Bashir, "Scientific concept of hearing and deaf students of grade VII," Journal Elementary Education, vol.23(1),pp 1-12, 2013

[2] W. Harlen, "Purposes and procedures for assessing process skills," Assessment in Education, vol.6 (1), pp129-140, 1999

[3] J. Huppert, S.M. Lomask, \& R. Lazarorcitz, "Computer simulations in the high school: Students' cognitive stages, science process skills and academic achievement in microbiology," International Journal of Science Education, vol.24(8), 803-821, 2002

[4] H. Aktamis, \& H. Ergin, "The effect of scientific process skills education on students' scientific creativity, science attitudes, and academic achievement", Asia-Pacific Forum on Science Learning and Teaching, vol.9(1), Article 4, 2008

[5] A.H. Zeidan, \& M. R. Jayosi, "Science process skills and attitudes toward science among Palestinian secondary school students." World Journal of Education, vol.5(1), pp 13-24, 2014

[6] M. Padilla, The science process skills. Research Matters-to the Science Teacher. No. 9004. Retrieved September 3, 2005 from https://www.narst.org/publications/research/skill.cfm, 1990

[7] R. M. Saat, "The acquisition of integrated science process skill in a web-based learning environment," Journal Research in Science \& Technological Education, vol.22(1), pp 23-40, 2004

[8] K. M. M. Monica, "Development and validation of a test of integrated science process skills for the further education and training learners," Dissertation, South Africa: Faculty of Natural and Agricultural science, University of Pretoria, .

[9] T. Ngoh, "Mastery of the science process skills," Unpublished manuscript. 2009

[10] V.M. Chabalengula, F. Mumba, \& S. Mbewe, " How pre-service teachers' understand and perform science process skills," Eurasia Journal of Mathematics, Science \& Technology Education, vol.8(3), pp 167-176, 2012

[11] S.A. Yalqin, U. Turgut, \& E. Buyukkasap, The effect of projectbased learning on science undergraduates' learning of electricity, attitude towards physics and scientific process skills. International Online of Educational Sciences, vol.1(1), pp 81-105, 2009.

[12] D.Z. Ozer, \& M. Ozkan, "The effect of the project-based learning on the science process skills of the prospective teachers of science," Journal of Turkish Science Education, vol.9(3), pp 131-136, 2012

[13] R. Omar, S.N. Puteh, \& Z. Ikhsan, "Implementation of science skills process in project-based learning through collaborative action research," Proceedings of the 7th International Conference on Educational Reform, Innovations and Good Practices in Education: Global Perspectives, pp 221-228, 2014
[14] Supriyatman \& Sukarno, "Improving science process skills (SPS) science concepts mastery (SCM) prospective student teachers through inquiry learning instruction model by using interactive computer simulation," International Journal of Science and Research, vol.3(2), pp 6-9, 2014

[15] N. Gultepe, \& Z. Kilic, 2015, "Effect of scientific argumentation on the development of scientific process skills in the context of teaching chemistry," International Journal of Environmental and Science Education, vol.10(1), pp 111-132, 2014

[16] T.J. Boudria, Implementing a project-based technology program for high school women. Community College Journal of Research \&Practice, Vol. 26(9), pp709-722, 2002

[17] S. Aladağ, "Effectiveness of project-based learning," Eurasian Journal of Educational Research, vol.32, pp 17-34, 2005

[18] J. Holbrook, "Education through science as a motivational innovation for science education for all," Science Education International, 21(2), 80-91, 2010

[19] Mundilarto, Kapita selekta pendidikan fisika (Capita Selecta of physics education), Yogyakarta: FMIPA UNY, 2002

[20] Haenudin, Pendidikan anak berkebutuhan khusus tunarungu (Education for children with special need: deaf), Jakarta: Luxima Metro Media. 2013

[21] S.D. Antia, P.B. Jones, S. Reed, \& K.H. Kreimeyer, "Academic status and progress of deaf and hard-of-hearing students in general education classrooms," The Journal of Deaf Studies and Deaf Education, vol.14(3), pp 293-311, 2009

[22] R.J. Rezba, C. Sprague, \& R. Fiel, Learning and assessing science process skills. Iowa: Kendall Hunt Publishing Company, 2003

[23] W. Harlen, \& J. Elstgeest, UNESCO sourcebook for science in the primary school. UNESCO Publications, 1992

[24] A.P. Sukarno, \& I. Hamidah, "The profile of science process skill (SPS) student at secondary high school (case study in Jambi)," International Journal of Scientific Engineering and Research (IJSER), vol.1, pp 79-83, 2013

\section{APPENDIX}

Appendix 1: List of the six selected journal articles

[1] Akram, B., Mehboob, R., Ajaz, A., \& Bashir, R. (2013). Scientific Concepts of Hearing and Deaf Students of Grade VIII. Journal of Elementary Education, 23(1), 1-12.

[2] Kurz, K. B., Schick, B., \& Hauser, P. C. (2015). Deaf children's science content learning in direct instruction versus interpreted instruction. Journal of Science Education for students with disabilities, 18(1), 3 .

[3] Mousley, K., \& Kurz, C. (2015). Pre-College Deaf Students' Understanding of Fractional Concepts: What We Know and What We Do Not Know. Journal of Science Education for Students with Disabilities, 18(1), 7.

[4] da Fonseca Flores, A. C., \& Rumjanek, V. M. (2015). Teaching science to elementary school deaf children in Brazil. Creative Education, 6(20), 2127.

[5] Zainuddin, N. M. M., Zaman, H. B., \& Ahmad, A. (2009). Learning Science Using AR-Book by Blended Learning Strategies: A Case Study on Preferred Visual Needs of Deaf Students. Journal of Educational Technology Development and Exchange, 9(2), 5-20.

[6] Gormally, C. (2017). Deaf, Hard-of-Hearing, and Hearing Signing Undergraduates' Attitudes toward Science in Inquiry-Based Biology Laboratory Classes. CBE-Life Sciences Education, 16(1), ar6. 